Jurnal Kesehatan Masyarakat

\title{
Factors Affecting the Use of Contraceptive in Indonesia: Analysis from the National Socioeconomic Survey (Susenas)
}

\author{
Haerawati Idris ${ }^{\bowtie}$ \\ Faculty of Public Health, Sriwijaya University
}

\section{Article Info}

Article History:

Submitted April 2018

Accepted July 2018

Published July 2019

\section{Keywords:}

contraceptive use, women,

socio-economic demo-

graphic factors, Susenas

\section{DOI}

https://doi.org/10.15294/

kemas.v15i1.14098

\begin{abstract}
Rapid population growth has become a major concern and attention of many national governments and international community. Most developing countries have acknowledged the role of family planning as an effective way to improve maternal/child health and suppress population growth. This study aimed to investigate the socioeconomic and demographic factors that influence the use of contraceptives in Indonesia. This was a cross-sectional study using secondary data derived from National Socio-Economic Survey (SUSENAS) in 2014. A sample of 286,695 married women was selected for this study. Multiple logistic regression analyses were used to estimate the effects of socio-economic and demographic variables on contraceptive use. Only $42 \%$ of married women in Indonesia used contraceptive method. The most popular contraceptive method was injection (55\%). Factors affecting contraceptive use were maternal age of 30-34 year, living in the urban area, family wealth status in the 4th quintile, secondary school, working women, residing in Java/Bali, and the number of living children $>2$. Family planning policy information, education, and communication program should consider these determinants of contraceptive use.
\end{abstract}

\section{Introduction}

Sustainable population growth is an important problem for developing countries (Earsido et al., 2015). To overcome this, the government developed policies to limit population growth. Family planning is a tool to control population growth (Mekonnen and Worku, 2011). Family planning is important as an efforts to reduce poverty, increasing economic growth, increasing women's productivity, reduce fertility, and improve the survival of children and mothers health. Family Planning can prevent maternal mortality up to 20-35\% (Gudaynhe et al., 2015).

Contraceptive use is considered as an important control measure of fertility (Asiimwe et al., 2013; Johnson, 2017). Contraceptive use is an effort to control population growth. The benefits of contraception can be divided into micro and macro levels. At the micro level, contraception is a measure to control the number of births and number of family members. Some forms of contraception also provide protection against sexually transmitted diseases (STDs). At the macro level, the benefit of contraception is limitation of population growth which results in reduction of burden in the national burden (Nonvignon and Novignon, 2014). Contraception should be given before menstruation returns in order to avoid pregnancy (Mindarsih et al., 2018)

Several factors have been identified to be

\footnotetext{
Correspondence Address:

J1. Raya Palembang-Unsri KM 32 Indralaya, Ogan Ilir Palembang

Email: haera@fkm.unsri.ac.id
} 
associated to the use of family planning method or contraceptives. These factors are social factors which includes economy, culture, and religion. The study by Kimani found that socio-economic variables, including education and wealth, were significant determinant of contraceptive use in Kenya. They also found that contraceptive use increased with less culture conservatism and the environment (Kimani et al., 2013). This study aimed to examine the social, economic, and demographic factors that influence the use of contraceptives in Indonesia.

The analysis was based on data from the National Social Economic Survey (Susenas) of 2014. Samples were collected from 286,695 married females. The National Social Economic Survey is a survey on consumption and expenditure at the household level. The Susenas survey has been conducted annually since 1963. It is aimed to collect a wide variety of social and demographic data, including those on education, health/nutrition, housing, other socio-economic aspects, social and cultural activities, consumption/expenditure and wealth status of the household level, travel and community perspectives on household welfare.

Susenas is divided into two types: a) Core Susenas, which is held annually, and b) Module Susenas, which is held once in three years. Core Susenas collects general data while Module Susenas collects more specific data. Core data are collected annually through core questionnaires while module data are collected through specific questionnaires and more detailed questions once every three years for every topic. The advantage of using Susenas data is that the survey covers very large samples from all provinces in Indonesia. The Susenas is designed to collect relatively extensive social and demographic data on an annual basis.

\section{Method}

This study used a cross-sectional design. The data were analyzed using univariate, bivariate, and multivariate analysis approaches. Univariate descriptive analysis was used to examine the distribution of the variable frequency. Bivariate analysis was used to identify the relationship between the independent variables and the use of contraceptives. The significant difference was established using chi-square $\mathrm{p}<0.05$. Logistic regression was used to examine the influence of the social, economic, and demographic factors on the use of contraceptives in Indonesia where the dependent variable was binary.

The dependent variable in the study was the use of contraceptives, which was collected from the question of whether female respondents were currently using contraceptives or not. If a female respondent reported that she was using a contraceptive method, it was coded as " 1 " and "0" for otherwise. Independent variables were selected to be used in the analysis based on the previous study that examined the association of the social, economic, and demographic factors in the use of contraceptives. The independent variables were maternal age, number of living children, level of wealth status, the status of residence, the status of the region, level of education, and work status.

\section{Results and Discussion}

Characteristic of Respondent

Table 1 presents the statistical summary of the samples used in the study. A total of $41.82 \%$ of respondents used contraceptives, with the majority using injection method (55\%). The majority of the respondents underwent primary education only (52.72\%), lived in rural areas (55.73\%), and lived in Java/Bali (35.32\%) and the eastern part of Indonesia (35.33\%).

Bivariate Analysis

Table 2 shows the statistical summary of the bivariate analysis. The use of contraceptives among married females increased when they were 35-39 year old and declined in age group $>40$. The low prevalence of contraceptives use among women aged $<30$ may be explained because most of them are newly married, and marriage is seen as a way to produce offspring. Newly married women might also have problems with accessing family planning services. The declining use of contraceptives among older women may be since they have reduced sexual activities. The use of contraceptives among married women increased with the women's level of education. The majority of contraceptives users were found in Java and Bali. This might be caused by better access to contraceptives in Java and Bali compared to other regions. 
Table 1. Characteristics of Respondents

\begin{tabular}{|c|c|}
\hline Characteristics & Total $(\mathrm{N}, \%)$ \\
\hline Total of respondent & 286,695 \\
\hline \multicolumn{2}{|l|}{ Use contraceptive } \\
\hline Yes & $119,886(41.82 \%)$ \\
\hline No & $166,809(58.18 \%)$ \\
\hline \multicolumn{2}{|l|}{ Age (year) } \\
\hline$<30$ & $53,554(18.68 \%)$ \\
\hline $30-34$ & $40,591(14.16 \%$ \\
\hline $35-39$ & $40,482(14.12 \%)$ \\
\hline $40-44$ & $38,371(13.38 \%)$ \\
\hline $45-49$ & $32,191(11.23 \%)$ \\
\hline$>49$ & $81,506(28.43 \%)$ \\
\hline \multicolumn{2}{|c|}{ Level of wealth status (per capita expenditure) } \\
\hline First quintile & $60,092(20.96 \%)$ \\
\hline Second quintile & $56,846(19.83 \%)$ \\
\hline Third quintile & $56,217(19.61 \%)$ \\
\hline Fourth quintile & $56,236(19.62 \%)$ \\
\hline Fifth quintile & $57,304(19.99)$ \\
\hline \multicolumn{2}{|l|}{ Work status } \\
\hline Work & $163,592(57.06 \%)$ \\
\hline No work & $123,103(42.94 \%)$ \\
\hline \multicolumn{2}{|c|}{ Number of living children } \\
\hline$>2$ & $131,659(45.92 \%)$ \\
\hline $1-2$ & $155,036(54.08 \%)$ \\
\hline \multicolumn{2}{|l|}{ Level of education } \\
\hline Primary & $151,134(52.72 \%)$ \\
\hline Secondary & $111,720(38.97 \%)$ \\
\hline Tertiary & $23,841(8.32 \%)$ \\
\hline \multicolumn{2}{|l|}{ Status of area } \\
\hline Urban & $126,931(44.27 \%)$ \\
\hline Rural & $159,764(55.73 \%)$ \\
\hline \multicolumn{2}{|l|}{ Region } \\
\hline Sumatera & $84,149(29.35 \%)$ \\
\hline Java-Bali & $101,260(35.32 \%)$ \\
\hline Eastern Indonesia & $101,286(35.33 \%)$ \\
\hline
\end{tabular}

Source: 2014 National Socio-economic Survey (SUSENAS) 
Table 2. Bivariate analysis between contraceptive use and independent variable

\begin{tabular}{|c|c|c|c|c|c|c|}
\hline \multirow{3}{*}{ Variables } & \multicolumn{5}{|c|}{ Contraceptive use } & \multirow{3}{*}{ OR (CI 95\%) } \\
\hline & \multicolumn{2}{|l|}{ Yes } & \multicolumn{2}{|c|}{ No } & & \\
\hline & $\mathrm{n}$ & $\%$ & $\mathrm{n}$ & $\%$ & & \\
\hline \multirow[t]{6}{*}{ Age (year) } & $<30$ & 30,726 & 57.37 & 22,828 & 42.63 & $0.61(0.60-0.61)^{\star * *}$ \\
\hline & $30-34$ & 25,470 & 62.75 & 15,121 & 37.25 & \\
\hline & $35-39$ & 25,538 & 63.08 & 14,944 & 36.92 & \\
\hline & $40-44$ & 21,400 & 55.77 & 16,971 & 44.23 & \\
\hline & $45-49$ & 11,841 & 36.78 & 20,350 & 63.22 & \\
\hline & $>49$ & 4,911 & 6.03 & 76,595 & 93.97 & \\
\hline \multirow{5}{*}{$\begin{array}{l}\text { Level of wealth } \\
\text { status }\end{array}$} & First quintile & 21,552 & 35.87 & 38,540 & 64.13 & $1.04(1.03-1.05)^{\star * *}$ \\
\hline & $\begin{array}{l}\text { Second } \\
\text { quintile }\end{array}$ & 25,000 & 43.98 & 31,846 & 56.02 & \\
\hline & Third quintile & 25,019 & 44.50 & 31,198 & 55.50 & \\
\hline & $\begin{array}{l}\text { Fourth } \\
\text { quintile }\end{array}$ & 24,862 & 44.21 & 31,374 & 55.79 & \\
\hline & Fifth quintile & 23,453 & 40.93 & 33,851 & 59.07 & \\
\hline \multirow[t]{2}{*}{ Work status } & Work & 67,988 & 41.56 & 95,604 & 58.44 & $0.86(0.84-0.87)^{\star \star}$ \\
\hline & No work & 51,898 & 42.16 & 71,205 & 57.84 & \\
\hline \multirow{2}{*}{$\begin{array}{l}\text { Number of } \\
\text { living children }\end{array}$} & $>2$ & 46,234 & 35.12 & 85,425 & 64.88 & $0.59(0.58-0.60)^{\star * *}$ \\
\hline & $1-2$ & 73,652 & 47.51 & 81,384 & 52.49 & \\
\hline \multirow{3}{*}{$\begin{array}{l}\text { Level of } \\
\text { education }\end{array}$} & Primary & 53,048 & 35.10 & 98,086 & 64.90 & $1.42(1.41-1.44)^{\star * *}$ \\
\hline & Secondary & 56,706 & 50.76 & 55,014 & 49.24 & \\
\hline & Tertiary & 10,132 & 42.50 & 13,709 & 57.50 & \\
\hline \multirow[t]{2}{*}{ Status of area } & Urban & 50,540 & 39.82 & 76,391 & 60.18 & $0.86(0.84-0.87)^{\star * *}$ \\
\hline & Rural & 69,346 & 43.41 & 90,418 & 56.59 & \\
\hline \multirow[t]{3}{*}{ Region } & Sumatera & 34,320 & 40.78 & 49,829 & 59.22 & $0.98(0.97-0.99)^{* * *}$ \\
\hline & Java-Bali & 44,914 & 44.36 & 56,346 & 55.64 & \\
\hline & $\begin{array}{l}\text { Eastern } \\
\text { Indonesia }\end{array}$ & 40,652 & 40.14 & 60,634 & 59.86 & \\
\hline
\end{tabular}

Source: 2014 National Socio-economic Survey (SUSENAS),

Key: ${ }^{* *}$ significant at $1 \%$ level; ${ }^{\star *} 5 \%$ level; ${ }^{\star} 10 \%$ level

Multivariate Analysis

All variables that were found to be statistically significant in the bivariate analysis were used to establish the determinant factors in the use of contraceptives among women using multivariate logistic regression analysis. The analysis was carried out using logistic regression model to calculate the odds ratio and $\mathrm{p}$-value. The variables that were found to be statistically significant in the use of contraceptives after keeping the other explanatory variables constant are presented in Table 2 . The results of logistic regression analysis showed that the variables that explain most of the variations in the use of contraceptives in Indonesia were: age, the status of the region, level of wealth status, level of education, number of living children, and work status. The respondents' age is one 
Table 3. Multivariate analysis

\begin{tabular}{|c|c|c|c|c|}
\hline Variable & Category & OR & $\mathrm{CI}$ & $\mathrm{p}$ \\
\hline \multirow[t]{6}{*}{ Age (year) } & $<30$ (ref) & & & 0.000 \\
\hline & $30-34$ & 1.16 & $1.13-1.20$ & \\
\hline & $35-39$ & 1.09 & $1.06-1.12$ & \\
\hline & $40-44$ & 0.76 & $0.74-0.78$ & \\
\hline & $45-49$ & 0.33 & $0.32-0.34$ & \\
\hline & $>49$ & 0.03 & $0.03-0.03$ & \\
\hline \multirow[t]{5}{*}{ Level of wealth status } & quintile 1 (ref) & & & 0.000 \\
\hline & quintile 2 & 1.19 & $1.16-1.22$ & \\
\hline & quintile 3 & 1.21 & $1.18-1.25$ & \\
\hline & quintile 4 & 1.25 & $1.22-1.29$ & \\
\hline & quintile 5 & 1.19 & $1.15-1.22$ & \\
\hline \multirow[t]{2}{*}{ Work status } & No work (ref) & & & 0.000 \\
\hline & Work & 0.95 & 0.94- 0.97 & \\
\hline \multirow[t]{2}{*}{ Number of living children } & $1-2(\mathrm{ref})$ & & & 0.000 \\
\hline & $>2$ & 1.56 & $1.53-1.59$ & \\
\hline \multirow[t]{3}{*}{ Level of education } & Primary (ref) & & & 0.000 \\
\hline & Secondary & 1.06 & $1.04-1.08$ & \\
\hline & Tertiary & 0.86 & $0.83-0.89$ & \\
\hline \multirow[t]{2}{*}{ Status of area } & Rural (ref) & & & 0.000 \\
\hline & Urban & 0.82 & $0.81-0.84$ & \\
\hline \multirow[t]{3}{*}{ Region } & $\begin{array}{l}\text { Eastern Indonesia } \\
\text { (ref) }\end{array}$ & & & 0.000 \\
\hline & Java-Bali & 1.68 & $1.64-1.72$ & \\
\hline & Sumatera & 1.11 & $1.09-1.14$ & \\
\hline
\end{tabular}

Source: 2014 National Socio-economic Survey (SUSENAS)

of the variables that influence the current use of contraceptives in Indonesia. Women in the age group 30-34 were 1.16 times more likely to use contraceptives than women in age group $<30$ while women in the age group 35-39 were 1.09 times more likely to use contraceptives than women in age group $<30$. The decrease in odds ratio with the increase of the respondent's age may reflect a decline in the use of contraceptives among older women.

Indonesian women living in urban areas were 0.82 times more likely to use contraceptives than those living in rural settings. The results of the analysis showed that the level of education among women is one of the predictors in the use of contraceptives in Indonesia. Women with secondary education are 1.06 times more likely to use contraceptives than those with a low level of education. The analysis also shows that the number of living children also influences the use of contraceptives. Women with $>2$ children were 1.56 times more likely to use contraceptives than those with 1 to 2 children. The work status also influences the use of contraceptives in Indonesia. Working women were 0.95 times more likely to use contraceptives than those who were not working. Women who live in urban areas were 0.82 times more likely to use contraceptives than women who live in rural areas. Women who live in Java-Bali region were 
1.68 times more likely to use contraceptives compared to the women in the eastern part of Indonesia. Women who were at the $4^{\text {th }}$ quintile in terms of wealth are 1.25 times more likely to use contraceptives than women who were at the $1^{\text {st }}$ quintile.

The study aimed to examine the social, economic, and demographic factors that are associated with the use of contraceptives in Indonesia. The results of the analysis indicate that all variables used in the study have a significant influence on the use of contraceptives. Some studies have indicated the positive correlation between the use of contraceptives and level of education (Larsson and Stanfors, 2014, Kimani et al., 2013, Nonvignon and Novignon, 2014, Asiimwe et al., 2013, Jalango et al., 2017, Rutaremwa et al., 2015). This is indicative that the higher the level of education among women, the higher the use of contraceptives. Use of contraceptives is also higher in urban areas than in rural areas. Survey held in some countries by reported that contraceptive use was higher among women from the urban than rural areas. (Nonvignon and Novignon, 2014, Johnson, 2017, Pandey and Singh, 2015, Unumeri et al., 2015). This may have been the result of different availability of social services, including information related to methods of contraceptives, access to contraceptives, and the needed health care services. Kimani et al. mentioned that ignorance regarding family planning methods and peculiar cultural factors might pose limitations to the use of contraceptives in rural areas (Kimani et al., 2013)

Age has a significant correlation with contraceptive use. Previous studies have demonstrated a significant relationship between age and contraceptive use (Ndugwa et al., 2011; Elfstrom and Stephenson, 2012; Rutaremwa et al., 2015). The work status of women has also been linked with the use of contraceptives. Women's employment status significantly predicted uptake contraceptive. Women who were in employment were more likely to use contraceptives. The previous study has mentioned that there is a relationship between contraceptive and employment. (Jalango et al., 2017, Pasha et al., 2015, Rutaremwa et al., 2015)

Wealth statushasa significant relationship with contraceptive use. The results indicated a direct relationship between women's wealth status and contraceptive use. Women from wealthier households are more likely to use contraceptive compared to those in the poorest households. Several studies have found the same result (Adebowale et al., 2014; Rutaremwa et al., 2015; Johnson, 2017; Anasel and Mlinga, 2014; Abraha et al., 2018). The number of living children has a significant correlation with the contraceptive. The previous study has explored that a higher number of living children were more likely to use contraceptive (Rutaremwa et al., 2015, Unumeri et al., 2015)

The limitation of this study was that there were some variables which had not been examined in this study due to lack of coverage of these variables in this survey like knowledge of women, exposure to media, husband's approval which is very important in the decision concerning the use of contraceptives. Despite such limitation, it is hoped that this study will provide information concerning the factors associated with the use of contraceptives in Indonesia.

Most developing countries have recognized family planning as an effective way to improve maternal and child health. It also has major role in mortality and transitional fertility. Family planning also influences women's empowerment. To improve the coverage of the use of contraceptives, it is necessary to identify the determinants of the use of contraceptives. To explain these differences, this paper aims at examining the relationship between the chosen social and economic variables and the use of contraceptives among married women in Indonesia. The results of multivariate analysis indicated that age, economic well-being, level of education, number of living children, and region of residence are the most important explanatory variables of the current use of contraceptives in Indonesia. These factors should be taken into account in the re-design of the national family planning programs in Indonesia. The government should improve and intensify further provision of information, educational, and communication programs concerning the use of contraceptives.

\section{Conclusions}

Factors affecting contraceptive use 
were maternal age of 30-34 year, living in the urban area, family wealth status in quintile 4 , secondary school, work, residing in Java/ Bali, the number of living children $>2$. Family planning policy information, education, and communication program should consider these determinants of contraceptive use.

\section{References}

Abraha, T.H., Gebrezgiabher, B.B., Aregawi, B.G., Belay, D.S., Tikue, L.T. \& Welay, G.M. 2018. Predictors of Postpartum Contraceptive Use in Rural Tigray Region, Northern Ethiopia: A Multilevel Analysis. BMC public health, 18, 1017.

Adebowale, S.A., Adedini, S.A., Ibisomi, L.D. \& Palamuleni, M.E. 2014. Differential Effect of Wealth Quintile on Modern Contraceptive Use and Fertility: Evidence from Malawian Women. BMC women's health, 14, 40.

Anasel, M.G. \& Mlinga, U.J. 2014. Determinants of Contraceptive Use among Married Women in Tanzania: Policy Implication. African Population Studies, 28, 976-988.

Asiimwe, J., Ndugga, P. \& Mushomi, J. 2013. SocioDemographic Factors Associated with Contraceptive Use among Young Women in Comparision with Older Women in Uganda.

Earsido, A., Gebeyehu, A. \& Kisi, T. 2015. Determinants of Long Acting and Permanent Contraceptive Methods Utilization among Married Women in Hossana Town, Southern Ethiopia: A Case-Control Study. J Preg Child Health, 2, 2.

Elfstrom, K.M. \& Stephenson, R. 2012. The Role of Place in Shaping Contraceptive Use among Women in Africa. PloS one, 7, e40670.

Gudaynhe, S.W., Zegeye, D.T., Asmamaw, T. \& Kibret, G.D. 2015. Factors Affecting the Use of Long-Acting Reversible Contraceptive Methods among Married Women in Debre Markos Town, Northwest Ethiopia 2013. Global Journal of Medical Research.

Jalang', R., Thuita, F., Barasa, S.O. \& Njoroge, P. 2017. Determinants of Contraceptive Use among Postpartum Women in a County Hospital in Rural Kenya. BMC public health, 17,604 .

Johnson, O.E. 2017. Determinants of Modern Contraceptive Uptake among Nigerian Women: Evidence from the National Demographic and Health Survey. African journal of reproductive health, 21, 89-95.

Kimani, M., Njeru, M. \& Ndirangu, G. 2013. Regional Variations in Contraceptive Use in Kenya: Comparison of Nyanza, Coast and Central Provinces. African Population Studies, 27.

Larsson, C. \& Stanfors, M. 2014. Women's Education, Empowerment, and Contraceptive Use in Sub-Saharan Africa: Findings from Recent Demographic and Health Surveys. African Population Studies, 28, 1022-1034.

Mekonnen, W. \& Worku, A. 2011. Determinants of Low Family Planning Use and High Unmet Need in Butajira District, South Central Ethiopia. Reproductive Health, 8, 37.

Mindarsih, T., Ludji, I.D.R. \& Pelokilla, M.L. 2018. Counseling and Individual Factors on Postpartum Mother to Use Contraceptive Method. Jurnal Kesehatan Masyarakat, 14.

Ndugwa, R.P., Cleland, J., Madise, N.J., Fotso, J.-C. \& Zulu, E.M. 2011. Menstrual Pattern, Sexual Behaviors, and Contraceptive Use among Postpartum Women in Nairobi Urban Slums. Journal of Urban Health, 88, 341-355.

Nonvignon, J. \& Novignon, J. 2014. Trend and Determinants of Contraceptive Use among Women of Reproductive Age in Ghana. African Population Studies, 28, 956-967.

Pandey, A. \& Singh, K. 2015. Contraceptive Use before First Pregnancy by Women in India (2005-2006): Determinants and Differentials. BMC public health, 15, 1316.

Pasha, O., Goudar, S.S., Patel, A., Garces, A., Esamai, F., Chomba, E., Moore, J.L., Kodkany, B.S., Saleem, S. \& Derman, R.J. 2015. Postpartum Contraceptive Use and Unmet Need for Family Planning in Five Low-Income Countries. Reproductive health, 12, S11.

Rutaremwa, G., Kabagenyi, A., Wandera, S.O., Jhamba, T., Akiror, E. \& Nviiri, H.L. 2015. Predictors of Modern Contraceptive Use During the Postpartum Period among Women in Uganda: A Population-Based Cross Sectional Study. BMC public health, 15, 262.

Unumeri, G., Ishaku, S., Ahonsi, B. \& Oginni, A. 2015. Contraceptive Use and Its SocioEconomic Determinants among Women in North-East and North-West Regions of Nigeria: A Comparative Analysis. African Population Studies, 29. 